急性アルュール投与ラットの肝再生に括ける Immunoreactive

Ornithine Decarboxylase の変動と性差について

$\begin{array}{cccccl}\text { 中島 } & \text { 尚登 } & \text { 山内 } & \text { 真義 } & \text { 平川 } & \text { 淳一 } \\ \text { 大畑 } & \text { 充 } & \text { 中山 } & \text { 一 } & \text { 中原 } & \text { 正雄 } \\ \text { 北原 } & \text { 敏久 } & \text { 藤沢 } & \text { 洌 } & \text { 亀田 } & \text { 治男* }\end{array}$

要 旨：肝再生の鋭敏な指標である ornithine decarboxylase (ODC) 活性と immunoreactive ODC (IR-ODC) 蛋白量を測定し ethanol (EtOH) の肝再生抑制作用に及ぽす性差の影響を検 討した。体重 $180 \mathrm{~g}$ の SD 系雄・雌 rat に Higgins の方法で肝部分切除を行い，直後に EtOHを $5 \mathrm{~g} / \mathrm{kg}$ ( $\mathrm{E}$ 群)，等 calorie の糖液 ( $\mathrm{C}$ 群) 投与を行い， $0 ， 4 ， 8 ， 12 ， 24$ 時間後に肝重量，総 蛋白量, DNA 合成の指標として ${ }^{3} \mathrm{H}$-Thymidine の取り込み, 肝可溶性分画の ODC 活性と IR -ODC 蛋白量を測定した。肝重量, 総蛋白量の増加及び DNA の合成の六進は, 特に雌の $\mathrm{E}$ 群 で有意に抑制された。訮 ODC 活性と IR-ODC 蛋白量は平行して 2 峰性に変動したが， 4 時間後 には雌の $\mathrm{E}$ 群で有意に $(\mathrm{p}<0.05)$ 減少し， 8 時間では雄・崔共 $\mathrm{E}$ 群で有意に減少した。以上の 成績から，雌 $\mathrm{E}$ 群では雄 $\mathrm{E}$ 群に比べて， EtOH 投与に上る肝再生の抑制は有意であり，IR-ODC 蛋白量は肝再生の良い指標であることが明らかになった。

索引用語 : ornithine decarboxylase immunoreactive ornithine decarboxylase エタール 肝再生 性差

\section{緒 言}

臨床疫学的研究から女性は男性に比べ少量短期間の 领酒で肝硬变になる事 ${ }^{1 \sim 3}$ が明らかにされており，我々 は，その一因として男女間における ethanol（以下 EtOH）代謝能に差異が存在するこどを報告してき

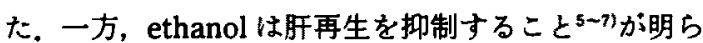
かにされているが，その再生抑制作用に及ばす性差の 影留をみた報告はない，また，肝の再生過程において 肝 ornithine decarboxylase (以下 ODC) 活性が鋭敏 な指標であるとする報告8 111は見られるが，性差につ いての検討はなされていないまた ODC 活性の測定 に当っては，ODCに結合して活性を失活させる antizyme の存在が問題となる。そこで我々は，雄・雌 rat に EtOH 急性負荷 $し$, 肝 ODC 活性と共に, Immunoreactive ODC (以下 IR-ODC) 蛋白量を测定し, これらの变動から EtOH の肝再生抑制作用に及はすす 泩差の意義を明らかにしたので報告する。

- 東京慈恵会医科大学第 1 内科 〈受付日1989年11月16日 $>$

\section{実験方法}

体重180g の Sprague-Dawley 系雄・雌 rat 各 5 匹を 12時間の䋓食後，ether 麻酶下で Higgins の方法 ${ }^{12)}$ 午前 9 時に肝の部分切除を行ない，直後に $20 \% の$ $\mathrm{EtOH}$ 溶液を $5 \mathrm{~g} / \mathrm{kg}$ の割合で経胃的に投与したものを EtOH 群とし，0，4，8，12，24時間後に肝再生の指 標として残存肝の重量の变動, 残存肝総蛋白量の变動, 肝可溶性分画の ODC 活性值及び IR-ODC 蛋白量を测 定した，また，肝再生のもら一つの指標として，肝部 分切除・EtOH 負荷後の 24 時間目 $K^{3} \mathrm{H}$-thymidine を腹 腔内に投与し，24時間目での thymidine の再生肝への 取り込みから DNA の合成を検討した。肝部分切除の 丸の対照群には，等カロリーの20\%榶液を投与し，同 様に㬰験を行った。

1）残存肝重量，残存肝総蛋白量の測定

$0 ， 4 ， 8 ， 12 ， 24$ 時間後に摘出した残存肝の肝重 量, 総蛋白量を測定し, 肝再生の指標とした。肝重量 は摘出後速やかに测定し, 残存肝の蛋白量は Lowry

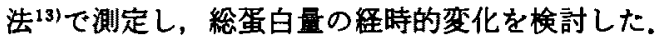

2) $\left[{ }^{3} \mathrm{H}\right]$-Thymidine の再生肝への取り込み 
肝部分切除・EtOH 負荷の24時間後に, [ $\left.{ }^{3} \mathrm{H}\right]$. thymidine $(20 \mu \mathrm{Ci}$ per mmole) を, 体重100g あたり $5 \mu \mathrm{Ci}$ 腹腔内に投与し，その 1 時間後に rat を実験に供 し, 肝 $1.0 \mathrm{~g}$ を 5 倍溶の, $5 \mathrm{mM}$ dithiothreitol (以下 DTT) 含む0.1M sodium phosphate buffer $(\mathrm{pH}$ 7.2)で homogenize した。この homogenate $0.5 \mathrm{~m} l \mathrm{~K}$ 等量の, $5 \%$ trichloroacetic acidを加元て擋拌, 5,000 gで 5 分以上遠心分離し，沈殿をさらに 3 回, trichloroacetic acid で擋䢁洗浄した後沈激の $\left[{ }^{3} \mathrm{H}\right]$ の放射性 活性を測定し， 1 分あたりの count 数 (cpm) を求め,

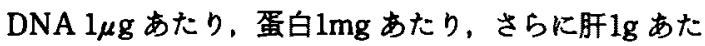
クの cpm として再生肝の index とした9). なお, DNA の定量は，前記 homogenate $0.5 \mathrm{~m} l$ を用いて SAN BIO 社製の DNA 定量 kit NUCLESAN 100で測定し た. また, sham operation 群についてす雄, 雌共に同 様に検討した。

\section{3） ODC 活性の湘定}

旰を摘出後，氷冷の生理食塩水で洗浄し, $5 \mathrm{mM}$ DTT を含んだ100mM の sodium phosphate buffer $(\mathrm{pH}$ 7.2)の 6 倍容とともに homogenize し, $30,000 \mathrm{~g} 25$ 分 間遠心分離して得られた上清について基質として DL.

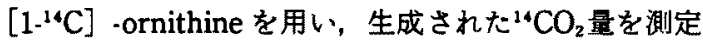
する林らの方法 ${ }^{14)}$ で ODC 活性值を測定した。すなわ $ち$ pyridoxal phosphate (以下 PLP) $0.04 \mathrm{mM}$, DTT $4 \mathrm{mM}$ を含む40mM $の$ Tris- $\mathrm{HCl}$ 㣪衙液 $(\mathrm{pH} 7.4) 10 \mu l$ $\kappa \mathrm{DL}-\left[1{ }^{14} \mathrm{C}\right]$-ornithine $50 \mu l$, 及 $ひ ゙$ homogenate 上 清 $65 \mu l$ を加えて37 C を50 $\mu l$ 加えて反応を止め，生成された ${ }^{14} \mathrm{CO}_{2}$ をろ紙(東 洋ろ紙No. 50）に吸收させ，その放射線活性を液体 scintiration counter で测定した. ODC 活性値は，1 時間当りに1nmole $の^{14} \mathrm{CO}_{2}$ を産生する量を基準とし た.

\section{4) IR-ODC 蛋白田の測定}

IR-ODC 蛋白量の测定は，前記 homogenateの上清 について，西山・林ら ${ }^{15)}$ の開発した mouse 蜸 ODCに 対する rabbit 抗 ODC-IgG polyclonal 抗体を用いた EIA 法で測定した，抗体の作成は西山ら ${ }^{15)}$ の精製法に よった. 即ち, 100 匹の雄 adult ICR-mouse の 1 匹当た りに25mg の testosterone enanthate を皮下注射し， 1 週間後に婜搭200個を摘出して buffer A [25mM Tris- $\mathrm{HCl}$ (pH 7.5) containing $1 \mathrm{mM} \mathrm{DTT,} 0.1 \mathrm{mM}$ EDTA, $40 \mu \mathrm{M}$ PLP, $0.2 \mathrm{M}$ sucrose and $1 \mathrm{mM}$ nafamostat mesilate] $\tau$ homogenize $L, 100,000 \mathrm{~g} \tau$ 60分遠心して上清を得た，この上清を $1 / 2$ 思の DEAE.
Cellurofine に通した後，buffer A 中の $\mathrm{NaCl}$ 濃度が， 0ー0.5M になるように, 上清の 3 倍容で linear gradientをかけて $10 \mathrm{~m} l$ ずつ fraction collecterで分取し て, ODC 活性のある fractionを分画した. 次に当大学 栄羡学教室より供与を受けた，松藤ら ${ }^{16)}$ の開発した monoclonal anti-ODCを用いて immunoaffinity-adsorbent column (HO-101-Affi-Gel 10 column) に活 性のある fraction を通し, $25 \mathrm{mM}$ TRIS-HCl(pH 7.5) containing $3 \mathrm{M} \mathrm{MgCl}_{2}, 1 \mathrm{mM}$ dithiothreitol and 0.01\% Tween 80で ODC 蛋白を溶出した。 これを buffer A で透析し, 濃縮した後 rabbitに皮下投与し抗 体を得た。

この抗体で固相化した polystiren tubeに酵素液を $200 \mu l$ 加え， $4{ }^{\circ} \mathrm{C}$ で一夜反応後，10mM sodium phosphate buffer ( $\mathrm{pH} 7.0$ ) containing $0.5 \mathrm{M} \mathrm{NaCl} て 22$ 回洗浄した。その後, affunity-purified anti-ODC Fab'-perioxidase 抗体を加え，室温で 5 時間反応後， $10 \mathrm{mM}$ sodium phosphate buffer $(\mathrm{pH} \mathrm{7.0)}$ で 2 回洗 浄した後 $400 \mu l \quad 0.5 \%$ 3-p-hydroxyphenyl propionic acidを加えた. さらに $100 \mu l$ の, $0.03 \% \mathrm{H}_{2} \mathrm{O}_{2}$ in $0.1 \mathrm{M}$ sodium phosphate buffer (pH 7.0) を加えて反応を 開始， 1 時間後に $3 \mathrm{~m} l$ の0.1M glycine- $\mathrm{NaOH}$ buffer （pH 10.3）を加えて反心を停止させ，HITACHI 810 型虽光分光光度計を用いて虽光を測定した. Excitation wave $320 \mathrm{~nm}$, emission wave $405 \mathrm{~nm}$ で湘定し, $1 \mu \mathrm{g} / \mathrm{ml}$ の quinine sulfate in $1 \mathrm{~N} \mathrm{H}_{2} \mathrm{SO}_{4}$ を基準として 蛍光強度を算定した。 IR-ODC 蛋白量はこの EIA 法で $0.2 \mathrm{ng}$ から10ng まで測定可能であり, humanの ODC 蛋白む测定可能であった ${ }^{15,16)}$ (Fig. 1).

\section{実験結果}

\section{1) 残存旰重量，総蛋由兵の变化}

残存肝重量の経時的変化を Fig. 2 に示す. 雄では, 12時間目をでは, 肝部分切除のみの対照群と EtOH 群 の間には再生肝重量に有意な差を認めなかったが，24 時間目では EtOH 群の肝重量は対照群に比して有意 に $(\mathrm{p}<0.05)$ 減少しており，肝重量の增加は EtOH 群 で㧕制された。

雌の対照群と EtOH 群間では，12時間後から肝重量 に差を認め, 24時間後には, EtOH 群の肝重量は雄より b有意に（p<0.005）减少し，部分切除前值よりむ低 い値となった。

また，垡存肝の総蛋白量の変動も，Fig. 3 に示すよ 5 に，訮重量と同様な㑯向を示し，雄の肝蛋白量は, 24時間後に EtOH 群で有意に（p<0.025）低下した。 
Sandwich Enzyme Immunoassay for Ornithine Decarboxylase

\begin{tabular}{|c|}
\hline $\begin{array}{l}\text { Sample in a total volume of } 0.2 \mathrm{ml} \text { was incuvated } \\
\text { overnight at } 4^{\circ} \mathrm{C} \text { in the anti-ODC IgG-coated } \\
\text { polystylene tube. }\end{array}$ \\
\hline$\downarrow$ \\
\hline $\begin{array}{l}\text { Washed twice with } 10 \mathrm{mM} \text { sodium phosphate } \\
\text { buffer }(\mathrm{pH} 7.0) \text { containing } 3 \mathrm{M} \mathrm{NaCl} \text {. }\end{array}$ \\
\hline$\sqrt{1}$ \\
\hline $\begin{array}{l}\text { Incuvated further with affinity-purified anti-ODC } \\
\text { Fab-peroxidase conjugate }(6.2 \mathrm{ng} / \mathrm{tube}) \text { in } 0.2 \mathrm{ml} \\
\text { of } 10 \mathrm{mM} \text { sodium phosphate buffer }(\mathrm{pH} 7.0) \\
\text { containing } 0.1 \% \text { BSA and } 0.1 \mathrm{M} \mathrm{NaCl} \text { at room } \\
\text { temperature for } 5 \text { hours. }\end{array}$ \\
\hline$\sqrt{3}$ \\
\hline $\begin{array}{l}\text { Washed twice with } 10 \mathrm{mM} \text { sodium phosphate } \\
\text { buffer }(\mathrm{pH} 7.0) \text {. }\end{array}$ \\
\hline$\checkmark$ \\
\hline $\begin{array}{l}\text { Bound peroxidase activity was assayed at room } \\
\text { temperature for } 60 \text { min. using } 3 \text {-( } \mathrm{p} \text {-hydroxypheny) } \\
\text { propionic acid as a substance. }\end{array}$ \\
\hline$\sqrt{2}$ \\
\hline $\begin{array}{l}\text { Fluorescence intensity was measured using } 320 \mathrm{~nm} \\
\text { and } 405 \mathrm{~nm} \text { for excitation and emission wave } \\
\text { lengths, and standardized by adjusting the scale } \\
\text { to } 100 \text { with } 1 \mu \mathrm{g} / \mathrm{ml} \text { quinine sulfate in I N } \mathrm{H}_{2} \mathrm{SO}_{4} \text {. } \\
\text { Blank value was expressed as the fluorescence } \\
\text { intensity in the absence of ODC. }\end{array}$ \\
\hline
\end{tabular}

Fig. 1 The assay methods of sandwich enzyme immunoassay for ornithine decarboxylase

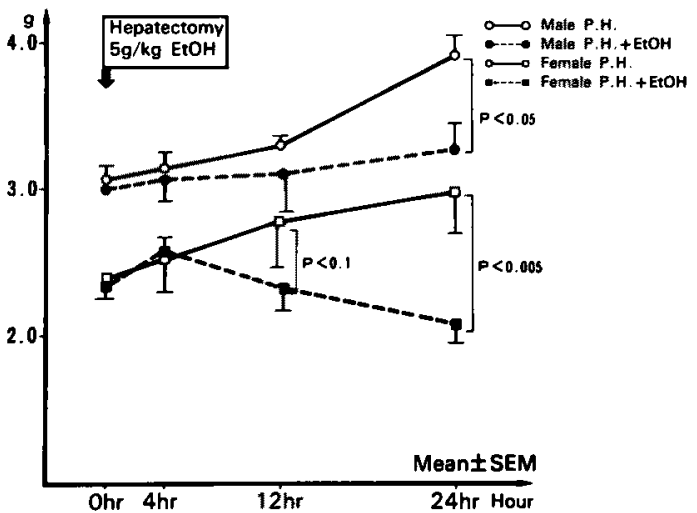

Fig. 2 Effect of $5 \mathrm{~g} / \mathrm{kg}$ ethanol administration and partial hepatectomy on the weight of regenerating rat liver

一方, 雌では12時間以降に減少し，雄との間に有意差 を諗め（p<0.05），24時間後には $\mathrm{p}<0.025$ の有意差で 著しく減少した。つまり，雌の $\mathrm{EtOH}$ 群で䏦再生は著 しく抑制された。

\section{2) [ $\left.{ }^{3} \mathrm{H}\right]$-Thymidine の再生肝への取り込み} 24時間目の [ $\left.{ }^{3} \mathrm{H}\right]$-thymidine $の$ 取り込友を Table 1

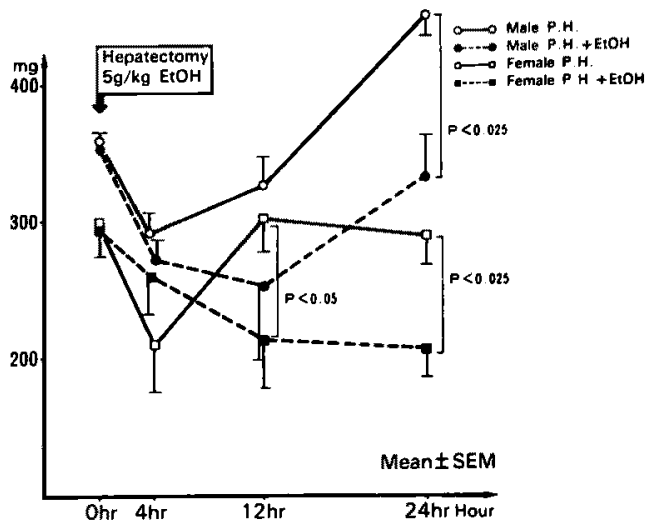

Fig. 3 Effect of $5 \mathrm{~g} / \mathrm{kg}$ ethanol administration and partial hepatectomy on the total liver protein contents of regenerating rat liver

Table 1 Hepatic incorporation of $\left[{ }^{3} \mathrm{H}\right]$. thymidine after partial hepatectomy and sham operation with acute ethanol administration (5 $\mathrm{g} / \mathrm{kg}$ ) in male and female rats.

\begin{tabular}{l|c|c} 
& \multicolumn{2}{c}{ (cpm/g liver) } \\
\hline & Male & Female \\
\hline Hepatectomy & $1598 \pm 159$ & $1678 \pm 159$ \\
Hepatectomy +EtOH & $1448 \pm 131$ & $1234 \pm 82^{\mathrm{a}}$ \\
Sham Operation & $1024 \pm 17$ & $858 \pm 3$ \\
\hline \multicolumn{3}{c}{ mean \pm SEM }
\end{tabular}

a : $p<0.05$ when compared to Hepatectomy group.

Table 2 Hepatic incorporation of $\left[{ }^{3} \mathrm{H}\right]$-thymidine after partial hepatectomy and sham operation with acute ethanol administration $(5 \mathrm{~g} / \mathrm{kg})$ in male and female rats.

(cpm/mg protein)

\begin{tabular}{l|c|c}
\hline & Male & Fernale \\
\hline Hepatectomy & $8.64 \pm 1.71$ & $11.47 \pm 2.46$ \\
Hepatectomy +EtOH & $8.22 \pm 1.88$ & $8.38 \pm 1.55^{\mathrm{a}}$ \\
Sham Operation & $4.82 \pm 0.16$ & $4.58 \pm 0.23$ \\
\hline \multicolumn{2}{|c}{ mean \pm SEM }
\end{tabular}

a : $p<0.05$ when compared to Hepatectomy group.

〜3に示す. 肝䐘 $1 \mathrm{~g}$ 当りの cpm は対照群では雄, 雌共 に差を認めなかったが，EtOH 群では対照群に比べ雌 で有意に取り込みが減少した $(p<0.05)$. た蛋白 $1 \mathrm{mg}$ 当りの cpm あ同様の傾向であったが, DNA $1 \mu \mathrm{g}$ 当り の cpmは, 対照群では雌で thymidine の取り込みは 有意に增加した。さらに雄の EtOH 群の0.71士0.18 $\mathrm{cpm} / \mu \mathrm{g}$ DNA と対照群の0.64 $00.13 \mathrm{cpm} / \mu \mathrm{g} / \mathrm{DNA}$ 
Table 3 Hepatic incorporation of $\left[{ }^{3} \mathrm{H}\right]$. thymidine after partial hepatectomy and sham operation with acute ethanol administration (5 $\mathrm{g} / \mathrm{kg}$ ) in male and female rats.

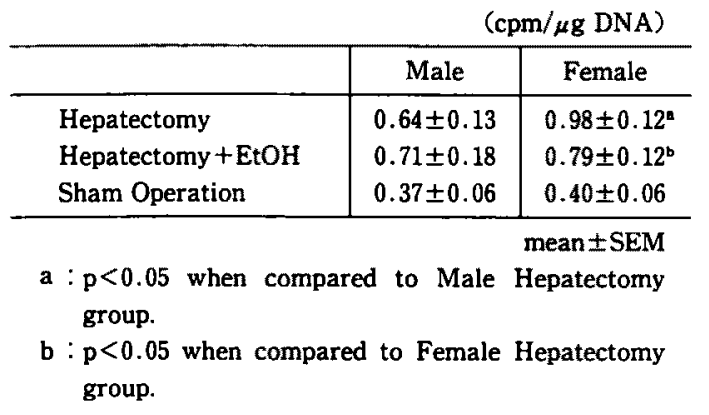

との間には有意差を認めなかったが, 雌の EtOH 群で

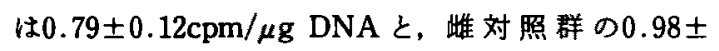
$0.12 \mathrm{cpm} / \mu \mathrm{g}$ DNA に比べて有意な低値を示し $(\mathrm{p}<$ 0.05), DNA 合成からみた肝再生は, 対照群では雌が 高く $(\mathrm{p}<0.05), \mathrm{EtOH}$ 投与によってさらに強く抑制 された。

\section{3） ODC 活性值の変動}

肝の ODC 活性值の変動を Fig. 4, Table 4 k示す. 活性値は雄, 倠共に 4 時間, 12時間を peak として2峰 性に変動した. 肝蛋白量 $1 \mathrm{mg}$ 当りの ODC 活性値を比 較すると，4 時間值では雄の対照群 $2.05 \pm 0.24 \mathrm{nmol}$ ${ }^{14} \mathrm{CO}_{2} / \mathrm{h} / \mathrm{mg}$ prot, EtOH 群2.34 $\pm 0.11 \mathrm{nmol}{ }^{14} \mathrm{CO}_{2} / \mathrm{h} /$ mg prot との間では有意な差を認めなかったが，雌の EtOH 群では1.33 $\pm 0.15 \mathrm{nmol}{ }^{14} \mathrm{CO}_{2} / \mathrm{h} / \mathrm{mg}$ prot と対

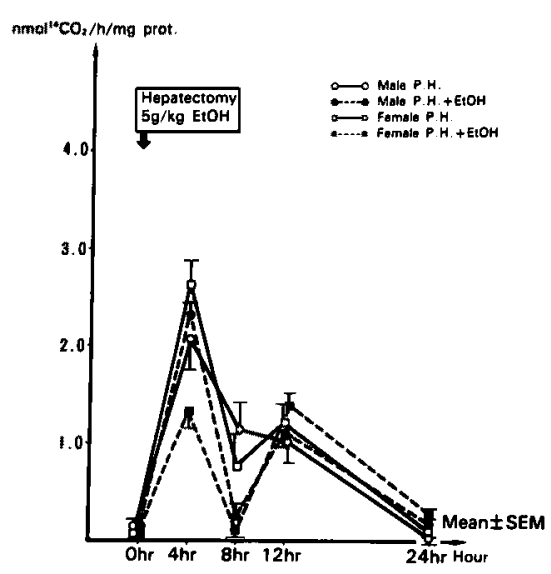

Fig. 4 Hepatic omithine decarboxylase activity after partial hepatectomy with ethanol administration $(5 \mathrm{~g} / \mathrm{kg})$

照群の2.84 $00.68 \mathrm{nmole}{ }^{14} \mathrm{CO}_{2} / \mathrm{h} / \mathrm{mg}$ protに比へ，有 意な低值を示した $(\mathrm{p}<0.1) .8$ 時間值では，雄・雙共 に EtOH 群で有意に低値を示し,とくに雌の EtOH 群 では最も低い值を示した。12時間では雄・雌の間で有 意差は認められなかったが, 24時間の EtOH 群で対照 群より有意に高くなり，とくに踓の EtoH 群では有意 な上昇が認められた $(p<0.05)$.

\section{4) IR-ODC 蛋白量の変動}

IR-ODC 蛋白量の変動を, Fig. 5, Table 5 に示す. ODC 活性值と同様に雄・倠共に 4 時間, 12時間を peak として 2 峰性に変動した。4 時間のIR-ODC 蛋白量 は, 雄の対照群で8.22 $\pm 0.14 \mathrm{ng} / \mathrm{mg}$ protein, EtOH 群

Table 4 Hepatic omithine decarboxylase activity after partial hepatectomy with ethanol administration $(5 \mathrm{~g} / \mathrm{kg})$.

\begin{tabular}{|c|c|c|c|c|c|}
\hline & \multicolumn{5}{|c|}{ ODC Activity (nmole ${ }^{10} \mathrm{CO}_{2} / \mathrm{h} / \mathrm{g}$ liver) } \\
\hline & $0 \mathrm{hr}$ & $4 \mathrm{hr}$ & $8 \mathrm{hr}$ & $12 \mathrm{hr}$ & $24 \mathrm{hr}$ \\
\hline Male P.H. & $0.86 \pm 0.14$ & $164.0 \pm 18.5$ & $84.9 \pm 13.1$ & $90.4 \pm 17.0$ & $4.07 \pm 1.40$ \\
\hline Male P.H. +EtOH & $0.77 \pm 0.19$ & $187.0 \pm 8.68$ & $17.5 \pm 4.96]^{\mathrm{e}}$ & $101.6 \pm 7.83$ & $15.6 \pm 3.15]^{d}$ \\
\hline Female P.H. & $0.92 \pm 0.10$ & $197.1 \pm 23.17_{\mathrm{h}} \mathrm{c}$ & $56.9 \pm 21.7_{7 \mathrm{~h}} \mathrm{a}$ & $116.9 \pm 17.0$ & $12.6 \pm 3.25$ \\
\hline \multirow[t]{3}{*}{ Female P.H. +EtOH } & $0.88 \pm 0.08$ & $121.0 \pm 16.8]$ & $7.1 \pm 1.255^{0}$ & $120.0 \pm 8.54$ & لـ \\
\hline & \multicolumn{5}{|c|}{ ODC Activity (nmole ${ }^{14} \mathrm{CO}_{2} / \mathrm{h} / \mathrm{mg}$ prot.) } \\
\hline & $0 \mathrm{hr}$ & $4 \mathrm{hr}$ & $8 \mathrm{hr}$ & $12 \mathrm{hr}$ & $24 \mathrm{hr}$ \\
\hline Male P.H. & $0.036 \pm 0.012$ & $2.05 \pm 0.24$ & $1.13 \pm 0.19$ & $1.02 \pm 0.17$ & $0.069 \pm 0.0237$ \\
\hline Male P.H.+EtOH & $0.010 \pm 0.002$ & $2.34 \pm 0.11$ & $0.24 \pm 0.06$ & $1.08 \pm 0.087$ & $0.167 \pm 0.034]^{b}$ \\
\hline Female P.H. & $0.008 \pm 0.001$ & $2.84 \pm 0.687 \mathrm{e}$ & $0.75 \pm 0.267_{\mathrm{b}}$ & $1.20 \pm 0.14 \mathrm{~b}$ & $0.106 \pm 0.030$ \\
\hline Female P.H.+EtOH & $0.008 \pm 0.001$ & $1.33 \pm 0.15^{[a]}$ & $0.10 \pm 0.02] \mathrm{b}]$ & $1.47 \pm 0.12$ & $0.236 \pm 0.031] \mathrm{c}$ \\
\hline
\end{tabular}

$a: p<0.1 \quad b: p<0.05 \quad c: p<0.025 \quad d: p<0.01 \quad$ e $: p<0.005$

Mean \pm SEM 
Table 5 Hepatic immunoreactive ornithine decarboxylase protein contents after partial hepatectomy with ethanol administration $(5 \mathrm{~g} / \mathrm{kg})$.

\begin{tabular}{|c|c|c|c|c|c|}
\hline & \multicolumn{5}{|c|}{ Immuonreactive $\mathrm{ODC}$ (ng/g liver) } \\
\hline & $0 \mathrm{hr}$ & $4 \mathrm{hr}$ & $8 \mathrm{hr}$ & $12 \mathrm{hr}$ & $24 \mathrm{hr}$ \\
\hline $\begin{array}{l}\text { Male P.H. } \\
\text { Male P.H.+EtOH } \\
\text { Female P.H. } \\
\text { Female P.H. +EtOH }\end{array}$ & $\begin{array}{l}22.4 \pm 3.83 \\
18.3 \pm 0.64 \\
23.9 \pm 1.50 \\
22.0 \pm 2.17\end{array}$ & 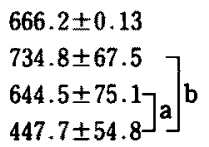 & $\left.\begin{array}{l}364.5 \pm 14.8 \\
142.0 \pm 28.7 \\
216.8 \pm 17.6 \\
121.5 \pm 7.83\end{array}\right] \mathrm{d}$ & $\begin{array}{l}325.2 \pm 74.3 \\
520.9 \pm 61.8 \\
451.6 \pm 30.0 \\
479.7 \pm 34.5\end{array}$ & 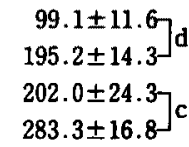 \\
\hline \multirow{2}{*}{ Female P.H.+EtOH } & \multicolumn{5}{|c|}{ Immuonreactive ODC (ng/mg prot) } \\
\hline & $0 \mathrm{hr}$ & $4 \mathrm{hr}$ & $8 \mathrm{hr}$ & $12 \mathrm{hr}$ & $24 \mathrm{hr}$ \\
\hline $\begin{array}{l}\text { Male P.H. } \\
\text { Male P.H. +EtOH } \\
\text { Female P.H. } \\
\text { Female P.H.+EtOH }\end{array}$ & $\begin{array}{l}0.21 \pm 0.03 \\
0.17 \pm 0.01 \\
0.19 \pm 0.03 \\
0.17 \pm 0.03\end{array}$ & $\left.\left.\begin{array}{l}8.22 \pm 0.14 \\
8.49 \pm 0.25 \\
8.95 \pm 1.55 \\
5.05 \pm 0.62\end{array}\right] \mathrm{c}\right] \mathrm{d}$ & $\left.\begin{array}{l}3.27 \pm 0.16 \\
1.38 \pm 0.26 \\
2.05 \pm 0.18 \\
1.14 \pm 0.10\end{array}\right] \mathrm{d}$ & $\left.\begin{array}{l}3.78 \pm 0.84 \\
4.95 \pm 0.41 \\
4.41 \pm 0.26 \\
5.81 \pm 0.60\end{array}\right] \mathrm{a}$ & 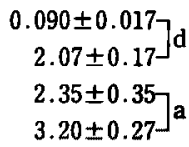 \\
\hline
\end{tabular}

a: $p<0.1 \quad b: p<0.01 \quad c: p<0.05 \quad d: p<0.005$

Mean \pm SEM

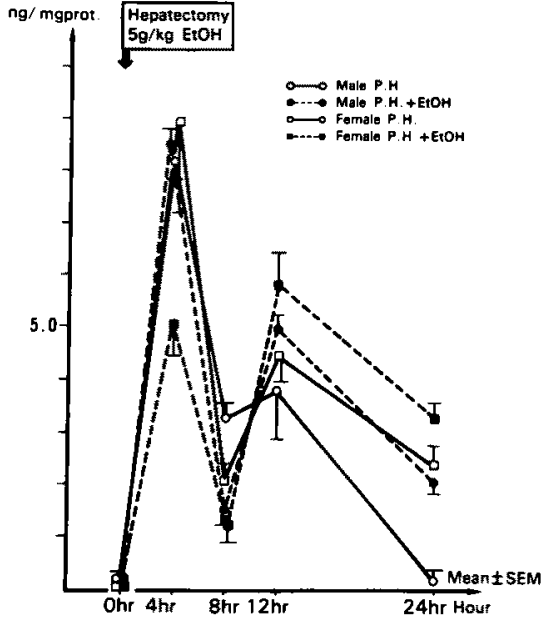

Fig. 5 Hepatic immunoreactive ornithine decar. boxylase protein contents after partial hepatectomy with ethanol administration $(5 \mathrm{~g} / \mathrm{kg}$ )

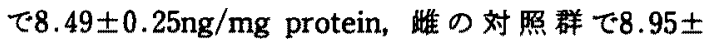
$1.55 \mathrm{ng} / \mathrm{mg}$ protein とこれらの間で有意差を認めな かったか;, 雌の EtOH 群では5.05 $0.62 \mathrm{ng} / \mathrm{mg}$ protein と他の群に比べて有意な低値を示した（p<0.05， $\mathrm{p}<0.005) .8$ 時間では，EtOH 群で有意な低值を示し ( $\mathrm{p}<0.005) ， 12$ 時間，24時間では各々の EtOH群で蛋 白量の増加㑯向を示し $(p<0.1)$, 特に雌の $\mathrm{EtOH}$ 群は 最る高い値を示した。すなわち，ODC 活性値と IRODC 蛋白量は，12時間で解離が認められた。
Ethanol が肝再生に抑制的に作用すること年文は，す でに明らかにされており，訮部分切除に EtOH の急性 負荷を行った報告では，EtOH の負荷量や負荷時間は さまざま検討されているが, Makowka ら゙は，EtOH の 2 回負荷では最高で89\%むDNA 合成が抑制された と報告している。また，慢性 $\mathrm{EtOH}$ 投与後に，肝部分

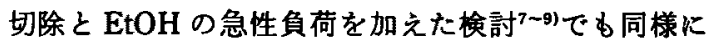
DNA 合成の抑制が認められている。一方, polyamine 釆の律速䤂である ODCについては，EtOHの急性 負荷，僈性投与後の急性投与どららでも肝再生の鋭敏 な指標となる 除と EtOH の急性負荷を加えた時の ODC の変動は, ODC 活性値は peak が所部分切除後4時間と10から12 時間の 2 蜂性に变動し，EtOH の負荷が加わると肝再 生が抑制され，それを反映して初めの peakである 4 時間目の ODC 活性値が低下する ${ }^{9,17)}$.

肝再生と性差については, testosterone 投与により, 肝部分切除後の再生が有意に九進したとの報告が(19,20) 見られるか，IR-ODC 蛋白量の変動と，性差の影暂も合 わせて同様に検討した報告は今までに無い，

肝部分切除とその直後に，EtOHを急性投与した今 回の条件下では，残存肝の重量と総蛋白量は雄の EtOH 群では対照群に比べて有意に抑制されていた が，とくに雌の EtOH 群では訮重量, 総蛋白量は著明 に增加が㧕制され，むしろ萎縮の傾向が認められた。 DNAの合成面から検討すると，雄・崔共に全ての群で shamoperationよりも有意にDNA は增加した。しか 
し，雄では EtOH 群，対照群の両者では DNA 合成に 有意差を認めなかったが，雌では対照群に比べて $\mathrm{EtOH}$ 群で DNA 合成は有意に抑制された，対照群で は雌の DNA 合成が增加していることから，雄に比べ て蜼では肝再生抑制作用が強く出現するといら結果が 得られた.これらの機序として,一つには, EtOH の急 性負荷で雌に括いて最高血中 EtOH 濃度が雄よりも 有意に高い4といらわれわれの結果を合わせて考える と，68\%の部分切除の直後に $5 \mathrm{~g} / \mathrm{kg}$ の EtOH を投与し たため，肝内・血中の EtOH 濃度が著しく上昇し，肝 再生が抑制され，その結果が ODC 活性，IR-ODC 蛋白 量に反映した可能性が示唆された。

ODC 活性は, 従来の報告8,9.16) どおり 2 峰性に变動し 4 時間の peak は，再生の抑制された崔の EtoH.群で 有意に低下した８時間以降では性差は認められなく なった. IR-ODC 蛋白量は, 活性值とほぼ平行して变動 し，4 時間では倠の EtOH 群で有意に低值をとった。 8 時間以降では活性值と同様に性差は認められなく なったが，12時間で活珄値との間に解離が認められ， またIR-ODC 蛋白量での検討の方が有意差が大きい 事から、これらの差異は EtOHによって ODCに対す る antizymeが多く誘導され，その影響による可能性 が示唆された。24時間の ODC 活性値と IR-ODC 蛋白 量は，共に EtoH 群で上昇し，特に肝再生の抑制され た崔の EtOH 群で高くなる佰向があり，急性負荷の田

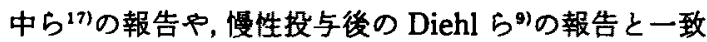
した。 また，肝部分切除後の ODCの初めの peak の ODCmRNA 量を検討した報告18)では，EtOH 投与は mRNA 量に影響しないことから, post. transcriptional regulation の関与が示唆されている. しかし、これまで性差についての検討はなされておら ず，遗伝子の level で踓雄間に肝再生に差があるか否 かは不明であるが，留䁍の ODC が testosterone で誘 導される15)ことを合わせて考えると，性木ルモンの ODC への影響を明らかにする必要がある。これらの肝 内 ODCの变動と，肝再生，DNA 合成を合わせて検討 すると，ODC 活性，IR-ODC 蛋白量は，倠の EtOH 群 の再生の抑制が初めての peak に反映され，IR-ODC 蛋白量の測定は antizymeの影響を受けないため，有 用性が高い再生の指標であると考えられた。

\section{結語}

雄・雌 rat 盰部分切除を加之，直後に $5 \mathrm{~g} / \mathrm{kg}$ の EtOH を急性負荷し，再生肝重量，総蛋白量，DNA 合 成，ODC 活性及び IR-ODC 蛋白巷を測定して以下の
結論を得た。

1. 肝部分切除後に EtOH を急性負荷すると, 雄で も肝再生は抑制されたが，雌の肝再生，DNA 合成は有 意に，抑制された。

2. 肝 IR-ODC 蛋白量は， ODC 活性と共に肝再生を 反映して 2 峰性に変動し, 踓の EtOH 群では初めの peak が有意に低下した。

3. IR-ODC 蛋白量は, antizyme の影響を受けない ため ODC 活性よりるより正確に肝再生を反映すると 考えられた。

以上の成績より，女性の方が小量かつ短期間でフル コール性肝硬変になる一因として, 男女間のアルコー ルの肝再生抑制作用の差異が考えられた。

稿を終るに当り，抗体を提供してくださり，終始御助言を 頂きました東京慈恵会医科大学栄养学林 伸一教授，松藤 千弥助手および西山正蟑助手に深謝致します。なお，本論文 の要旨は第31回日本消化器病学会大会 (旭川) で発表した。

本研究红, 1989年度文部省科学研究一般研究 C(課題番号 01570412）助成金で行った。

$$
\text { 文献 }
$$

1) Wilkinson P, Kornaczewski A, Rankin JG, et al: Physical disease in alcoholism: Initial survey of 1,000 patients. Med J Aust 1: 1217 $-1225,1971$

2) Pequignot G, Chabert $\mathrm{C}$, Eydoux $\mathrm{H}$, et al: Augumentation du risque de cirrhose en fonction de la ration d'alcohol. Rveue Alcoholism $20: 191-202,1974$

3) Morgan M, Sherlock S: Sex-related differences among 100 patients with alcoholic liver disease. Br Med J 1: 939-941, 1977

4）山内真義, 平川淳一，木村和夫，他：フルコール性 肝障害に及ぼす性羑の影辢。肝眼 $30: 643-648$, 1989

5) Craig J : Effects of ethanol and ethionine on DNA synthesis during experimental liver regeneration. J Studies Alcohol 36 : 148-157, 1975

6) Makowka L, Falk RE, Hardy M, et al : Reversal of ethanol-induced inhibition of hepatic regeneration by regenerating rat liver cytosol. Pharmacologist $23: 221,1981$

7) Wands JR, Carter EA, Bucher LR: Inhibition of hepatic regeneration in rats by acute and chronic ethanol intoxication. Gastroenterology 
$77: 528-531,1979$

8) Poso A, Poso H: Inhibition of ornithine decarboxylase in regy of the liver. I. Restoration of the liver of the white rat following partial surgical removal. Arch Pathol 12: 186-202, 1981

9) Diehl AN, Chacon M, Wagner P: The effect of chronic ethanol feeding on ornithine decarboxylase activity and liver regeneration. $\mathrm{He}$ patology $8: 237-242,1988$

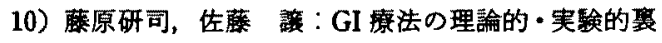
付け. 肝胆脺 $17: 799-805,1988$

11）林 伸一：肝再生の指標「肝荿フォーラム」. 原田 尚 編, 医事出版社，東京，1988，p90-103

12) Higgins GM, Anderson RM: Experimental pathology of the liver. I. Restoration of the liver of the white rat following partial surgical removal. Arch Pathol 12: 186-202, 1931

13) Lowry OA, Rosebrough NJ, Farr AL, et al : Protein measurement with the Folin phenol regent, J Biol Chem 193 : 265-275, 1951

14) Murakami Y, Kameji T, Hayashi S : Cysteine-dependent inactivation of hepatic or- nithine decarboxylase. Biochem J 217: 573 $-580,1984$

15) Nishiyama $M$, Matsufuji $S$, Kanamoto $R$, et al : Sandwich enzyme immunoassay for ornithine decarboxylase. J Immunoassay $10: 19-35,1989$

16) Nishiyama M, Matufuji S, Kamamoto $R$, et al : Two-step purification of mouse kidney ornithine decarboxylase. Preparative Biochem 18: $227-238,1988$

17）田中 隆, 井村万龟雄, 助川義寛, 他 : 肝部分切除 後肝再生におよばすェタノールの影㸷。第22回日 本フルコール医学会抄録集、254-255, 1988

18）田中 隆, 助川義宽, 西口平, 他：肝部分切除後 の訮 ODCmRNA 発現動態におよはすす急性ェタ ,ール投与の影謷. 日本消化器病学会抄録集 86 : 125,1989

19) Bengmark S, Olsson $R$ : The effect of testosterone on liver healing after partial hepatectomy, Acta Chir Scand 127 : 93-100, 1964

20) Patrice V, Bernard SA, Cecile A, et al : Complate liver regeneration in one-stage $90 \%$ hepatectomized rats treated with testosterone. Hepatology $2: 247-248,1982$

\title{
Sex difference in liver regeneration and ornithine decarboxylase protein after acute ethanol administration to hepatectomized rats
}

\author{
Hisato Nakajma, Masayoshi Yamauchi, Jyunichi Hirakawa, Mitsuru Oohata, \\ Hajime Nakayama, Masao NaKahara, Toshihisa Kitahara, \\ Kiyoshi FujISAwA and Haruo KAMEDA*
}

We studied the effect of acute ethanol administration and sex difference in ornithine decarboxylase (ODC) activity, immunoreactive ODC (IR-ODC) protein, DNA synthesis and liver regeneration. Male and female adult Sprague-Dawley rats, weighting about $180 \mathrm{~g}$, had a $68 \%$ hepatectomy accompanied by oral administration of $5 \mathrm{~g} / \mathrm{kg}$ of $20 \%$ ethanol as ethanol group. Control groups were given same calories of glucose solution. Rats were killed and the liver remnant weight, total protein contents of liver, DNA synthesis, hepatic ODC activity and IR-ODC protein were analyzed. Serially at $0,4,8,12,24$ hours after hepatectomy, IR-ODC protein was mesured by the methods of Hayasi (EIA assay). Liver weight, total protein contents and DNA synthesis were significantly decreased in female ethanol group. ODC activity and IR-ODC protein were significantly $(p<0.05)$ decreased in the same female ethanol group at 4 hours after hepatectomy. These data suggest that the acute ethanol administration suppress the liver regeneration more promidently in female rats liver than in male livers. IR-ODC protein is a good marker of liver regeneration.

\footnotetext{
* The First Department of Internal Medicine, The Jikei University School of Medicine (Tokyo)
} 